\title{
Copper Resistance in Pseudomonas syringae Strains Isolated from Mango Is Encoded Mainly by Plasmids
}

\author{
Francisco M. Cazorla, Eva Arrebola, Ane Sesma, Alejandro Pérez-García, \\ Juan C. Codina, Jesús Murillo, and Antonio de Vicente
}

First, second, fourth, fifth, and seventh authors: Departamento de Microbiología, Facultad de Ciencias, Universidad de Málaga, 29071 Málaga, Spain; and third and sixth authors: Instituto de Agrobiotecnología y Recursos Naturales, CSIC-UPNA and Laboratorio de Patología Vegetal, Escuela Técnica Superior de Ingenieros Agrónomos, Universidad Pública de Navarra, 31006 Pamplona, Spain. Accepted for publication 4 April 2002.

\begin{abstract}
Cazorla, F. M., Arrebola, E., Sesma, A., Pérez-García, A., Codina, J. C., Murillo, J., and de Vicente, A. 2002. Copper resistance in Pseudomonas syringae strains isolated from mango is encoded mainly by plasmids. Phytopathology 92:909-916.

Bacterial apical necrosis of mango, elicited by Pseudomonas syringae pv. syringae, limits fruit production in southern Spain and Portugal. Examination of a collection of $P$. syringae pv. syringae isolates for copper resistance showed that $59 \%$ were resistant to cupric sulfate. The survey of a mango orchard revealed an increase in frequencies of copperresistant bacteria after repeated treatments with Bordeaux mixture. These data suggest that selection of copper-resistant strains could be a major

reason for control failures following management with copper bactericides. Most copper-resistant isolates harbored plasmids, although the majority of them contained a $62-\mathrm{kb}$ plasmid that also was present in copper-sensitive strains. The $62-\mathrm{kb}$ plasmids were differentiated by restriction enzyme analysis and hybridization to $\operatorname{cop} A B C D$ DNA. The most frequently found copper-resistant plasmid type (62.1) was transferable by conjugation. Southern blot hybridizations showed that genetic determinants partially homologous to $\operatorname{cop} A B C D$ were present in all the copperresistant strains examined, and usually were associated with plasmids; these determinants were not detected in copper-sensitive strains. The selective pressure exerted by copper bactericide sprays on the diversity of copper resistance determinants in bacterial populations of mango is discussed.
\end{abstract}

Native to southern Asia, mango (Mangifera indica L.) is one of the most important fruit crops in the world. During the last 15 years, there has been a huge increase in mango production as markets have developed in Europe and North America (22). In Europe, most of the mango production is located in southern Spain and Portugal, where it has expanded steadily during the last 10 years. However, the commercial viability of this crop has been threatened by the frequent occurrence of bacterial apical necrosis, a newly reported disease of mango, which is caused by the phytopathogenic bacterium Pseudomonas syringae pv. syringae $(6,8)$. Symptoms include necrosis of flower buds, leaves, stems, and flower panicles; it causes severe economic losses due to the decrease in fruit set.

Growers in Spain and Portugal make extensive use of registered copper compounds, mostly Bordeaux mixture, to control bacterial apical necrosis (8). In the last few years, however, growers have noticed a reduction in the efficacy of the treatments which, in turn, has led to an increase in the dosage and frequency of copper applications (6). This scenario is common for $P$. syringae or Xanthomonas campestris diseases that have been repeatedly managed with copper and the lack of control is usually due to the emergence of copper-resistant $\left(\mathrm{Cu}^{\mathrm{r}}\right)$ bacteria $(1,10,24,30$, $35,39)$. However, to the best of our knowledge, there are no published reports of the isolation of $\mathrm{Cu}^{\mathrm{r}} P$. syringae in southern Europe although, in Spain, copper compounds routinely are used for the management of bacterial diseases of vegetable and tree crops (23).

Copper-resistance determinants have been cloned and characterized from strains of $P$. syringae and $X$. campestris, and frequently

Corresponding author: A. de Vicente; E-mail address: adevicente@uma.es

Publication no. P-2002-0528-03R

(C) 2002 The American Phytopathological Society were found associated with native plasmids $(5,9,19,21,34)$. Conjugative transfer of indigenous plasmids encoding copper resistance has been demonstrated for $P$. syringae and other phytopathogenic bacteria $(3,36,39)$, contributing to the dissemination of copper resistance (37). The copABCD genes, isolated from a $35-\mathrm{kb}$ plasmid of $P$. syringae pv. tomato (4), were the first such genes to be sequenced (25), and DNA cross-hybridizing to $\operatorname{cop} A B C D$ subsequently has been found in $\mathrm{Cu}^{\mathrm{r}}$ strains of $P$. syringae from impatiens (11), P. syringae pv. syringae (31), and a variety of $\mathrm{Cu}^{\mathrm{r}}$ and copper-sensitive $\left(\mathrm{Cu}^{\mathrm{s}}\right)$ Pseudomonas spp. $(12,43)$. In addition, copA, but not the rest of the cop operon, was shown to crosshybridize to the cloned copper-resistance determinants from $X$. campestris pvs. campestris and vesicatoria (42). A second copperresistance operon, located on the chromosome and designated copJ (28), has been found in a limited number of $\mathrm{Cu}^{\mathrm{r}} P$. syringae pv. syringae strains (31). Although copJ shares some structural similarities with $\operatorname{cop} A B C D$, it seems that it mediates resistance by a different mechanism, and the two determinants do not to crosshybridize (28,31). Also, purified DNA from certain $\mathrm{Cu}^{\mathrm{r}} P$. syringae pv. syringae strains did not hybridize to the cloned $\mathrm{Cu}^{\mathrm{r}}$ genes previously described (35). In a separate study, colony hybridization experiments using copABCD and copJ as hybridization probes failed to detect a portion of the $\mathrm{Cu}^{\mathrm{r}}$ strains of $P$. syringae pv. syringae (31). These studies suggest that $P$. syringae pv. syringae might harbor yet another type or types of $\mathrm{Cu}^{\mathrm{r}}$ determinant.

In this study, we provide evidence that $\mathrm{Cu}^{\mathrm{r}}$ strains of the pathogen and $\mathrm{Cu}^{\mathrm{s}}$ bacterial population pockets that seem to be protected from the bactericides could be responsible for the ineffectiveness of the chemical management strategies currently used for bacterial apical necrosis. We found a rich diversity of $\mathrm{Cu}^{\mathrm{r}}$ determinants among the $P$. syringae pv. syringae populations affecting mango trees, suggesting the acquisition of copper-resistance determinants from a variety of sources. 


\section{MATERIALS AND METHODS}

Isolation and phenotypic characterization of $P$. syringae pv. syringae. The 117 P. syringae pv. syringae strains studied in this work were isolated as previously described (8) from commercial mango orchards located in Faro (Portugal) and in different locations of Málaga and Huelva (Spain). Sampling was carried out from 1992 to 1999 in orchards repetitively treated with copper compounds, especially with Bordeaux mixture. Bacterial isolates were identified and characterized as described $(7,8)$ by using biochemical, physiological, and pathogenicity tests, and by evaluating the production of virulence factors.

Bacterial strains, plasmids, and culture conditions. The bacterial strains and plasmids used in this study are listed in Table 1. The 15 P. syringae pv. syringae strains isolated from mango trees described in Table 2 were selected from the 117 isolates obtained in this study as being representative of the different plasmid profiles and hybridization patterns observed. Escherichia coli was routinely grown in Luria-Bertani broth (LB) (29) at $37^{\circ} \mathrm{C}$ and $P$. syringae in King's medium B (KMB) or LB at $27^{\circ} \mathrm{C}$. Resistance to copper was determined by using mannitol-glutamateyeast extract medium (MGY) (3) amended with $\mathrm{CuSO}_{4} \cdot 5 \mathrm{H}_{2} \mathrm{O}$, using as inoculum bacteria that were previously grown for $48 \mathrm{~h}$ at $27^{\circ} \mathrm{C}$ on $\mathrm{KMB}$. Isolates were considered resistant to copper when their growth on $\mathrm{MGY}+0.8 \mathrm{mM} \mathrm{CuSO}_{4}$ after $72 \mathrm{~h}$ at $27^{\circ} \mathrm{C}$ was equivalent to that on MGY in the same conditions. The minimal inhibitory concentrations (MICs) for copper were determined by inoculating isolates on MGY plates containing copper from 0 to $3.6 \mathrm{mM}$ and measuring inhibition after $72 \mathrm{~h}$ at $27^{\circ} \mathrm{C}$. When necessary, media were supplemented with antibiotics at the following concentrations ( $\mu \mathrm{g} / \mathrm{ml})$ : ampicillin, 100 ; kanamycin, 30; and tetracycline, 15.

P. syringae pv. syringae FF5 is a copper-sensitive, plasmidless strain with a high efficiency of transformation by electroporation (35). A mating experiment with E. coli S17- $\lambda$ pir (mini-Tn5Km2) (14) as donor and strain FF5 as recipient was carried out to generate a kanamycin-resistant derivative by transposon mutagenesis. A stable kanamycin-resistant mutant was selected, designated FF5$\mathrm{km}$, and used as a copper-sensitive recipient strain in conjugation experiments.

P. syringae pv. syringae UMAF0049 is a $\mathrm{Cu}^{\mathrm{r}}$ strain that contains a 62-kb pPT23A-like plasmid and an additional 88-kb plasmid (6). The introduction into UMAF0049 of pAKC, which contains the origin of replication of the native plasmid pPT23A from P. syringae pv. tomato PT23 (26), led to the loss of the 88-kb plasmid. After repeated subculturing without antibiotic selection, pAKC was lost and the resulting strain, containing only the native $62-\mathrm{kb}$ plasmid, was retained and designated UMAF0049c4. The same procedure was followed with five other strains showing the same plasmid profile as UMAF0049 to obtain the corresponding derivatives cured of the 88 -kb plasmid.

Copper-based bactericide treatment and estimation of bacterial populations on mango buds. From 1997 to 2000, two groups of 12 mango trees (cv. Tommy Atkins) each, affected by apical necrosis at La Redondela (Huelva, Spain), were sampled to determine the occurrence of $P$. syringae and the proportion of $\mathrm{Cu}^{\mathrm{r}}$ bacteria in the bacterial population on buds. One group of trees was sprayed monthly with Bordeaux mixture $(3 \mathrm{~g} /$ liter) from September to June during the 3 years of study, while the other group was used as a nontreated control. Bulked samples of five buds

TABLE 1. Bacterial strains and plasmids and their relevant characteristics

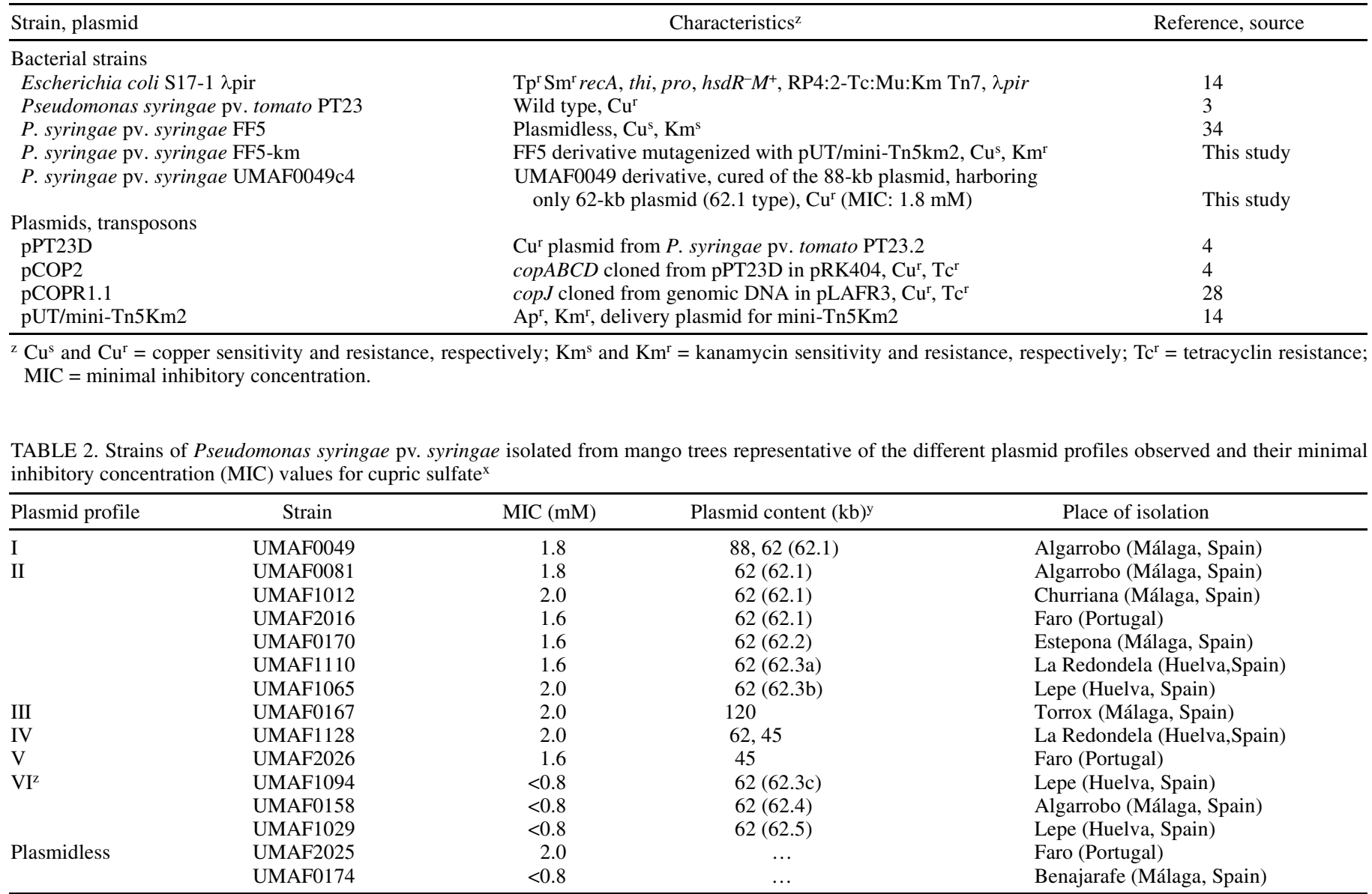

\footnotetext{
${ }^{\mathrm{x}}$ Strains with MIC values of $<0.8 \mathrm{mM}$ are considered sensitive to copper.

y Numbers and letters in parenthesis (62.1 to 62.5) indicate different restriction profiles with EcoRI of 62-kb plasmids.

${ }^{\mathrm{z}}$ Same plasmid profile as II, but considering only copper-sensitive strains.
} 
were randomly collected from each of the 24 trees in February, April, and June, every year of the study. $P$. syringae-like and total bacterial populations were determined as previously described (8). For each sample, the proportion of $\mathrm{Cu}^{\mathrm{r}}$ bacteria is expressed as the percentage of bacteria growing on $\mathrm{MGY}+0.8 \mathrm{mM}_{\text {of }} \mathrm{CuSO}_{4}$ with respect to the total bacterial population growing in MGY. Data were subjected to analysis of variance (ANOVA) followed by the least significant difference test $(P=0.01)$, using SPSS software (SPSS Inc., Chicago).

Plasmid characterization. Plasmid DNA was isolated according to a modified alkaline lysis method (44) and separated by electrophoresis on $0.6 \%$ agarose gels (27). Plasmid size was estimated by comparison with plasmids from $P$. syringae pv. tomato PT23. Purified plasmid DNA digested with EcoRI was separated by electrophoresis on $1 \%$ agarose gels and examined for restriction fragment length polymorphisms.

Mating experiments. Biparental matings were carried out to determine whether copper resistance genes were located on conjugative plasmids. After overnight growth in $\mathrm{LB}$, selected $\mathrm{Cu}^{\mathrm{r}} P$. syringae strains harboring $62-\mathrm{kb}$ plasmids were mixed in a $1: 1$ ratio with the copper-sensitive strain $P$. syringae pv. syringae FF5$\mathrm{km}$, and the mixtures were incubated overnight on $\mathrm{LB}$ at $27^{\circ} \mathrm{C}$. Transconjugants were selected on MGY amended with $1 \mathrm{mM}$ copper sulfate and kanamycin, and their MIC values for copper determined as described above. All mating combinations were repeated at least three times.

Southern blot analysis. Approximately $5 \mu \mathrm{g}$ of genomic or plasmid DNA was digested with EcoRI, separated by electrophoresis in $1 \%$ agarose gels, transferred to nylon membranes, and hybridized with radioactive probes following standard procedures (29). A 4.4-kb PstI fragment from pCOP2, containing the copABCD genes from $P$. syringae pv. tomato PT23 $(4,25)$, and a $2.8-\mathrm{kb}$ BamHI-Pst I fragment from pCOPR1.1, containing copJ from $P$. syringae pv. syringae AL513 (28), were labeled with $\left[\alpha{ }^{32} \mathrm{P}\right] \mathrm{dCTP}$ using the random primer method (29) and used as hybridization probes. Hybridizations and posthybridization washes at high-stringency $\left(65^{\circ} \mathrm{C}\right)$ or low-stringency $\left(42^{\circ} \mathrm{C}\right)$ conditions were carried out according to standard procedures (29). Hybridization signals were detected following a scan in a FUJI BAS 1500 equipment using a FUJIX BAS IP-CST 2040 cassette and analyzed with the MacBas software (FUJI Photo Film Co., Tokyo). All the different Southern blot experiments were performed at least twice.

\section{RESULTS}

Natural bacterial colonization of trees treated with Bordeaux mixture. Two groups of 12 mango trees each were sampled from 1997 to 2000 to determine the effect of treatment with Bordeaux mixture on the bacterial populations on buds. During these 3 years, both groups of trees were strongly affected by apical necrosis, with disease incidence ranging from 60 to $80 \%$ (data not shown). For all the sampling dates, more than $94 \%$ of the total isolates recovered from buds were fluorescent, oxidase-negative, arginine dihydrolase-negative pseudomonads and were consequently considered to be $P$. syringae-like. Both the total number of bacteria and the $P$. syringae-like counts did not differ significantly between buds from the trees treated with Bordeaux mixture and those from nontreated trees for any of the sampling dates; these population sizes were very similar throughout the experiment (Fig. 1A and B). However, after 1 year of treatment with Bordeaux mixture, the proportion of $\mathrm{Cu}^{\mathrm{r}}$ bacteria on buds of treated trees increased sharply to around $50 \%$ and remained at that level during the second and third years (Fig. 1C). Although a slight increase in the $\mathrm{Cu}^{\mathrm{r}}$ bacterial population on buds of nontreated trees also was observed during the experiment, these variations were not statistically significant.

Isolation of $\mathrm{Cu}^{\mathrm{r}}$ P. syringae pv. syringae strains from mango orchards. Between 1992 and 1999, 117 P. syringae strains were isolated from mango trees, either healthy or showing typical symptoms of bacterial apical necrosis, in eight different locations in southern Spain and Portugal. The isolates were phenotypically homogeneous, and all of them showed the following characteristics: they produced green fluorescent pigment; were oxidase and arginine dihydrolase negative; hydrolyzed esculin and gelatin; did not utilize sodium tartrate; were ice-nucleation active; elicited the hypersensitive response in tobacco; produced syringomycin; and were pathogenic on lilac, lemon, tomato, and pear, but not on bean pods (data not shown). Based on these characteristics, all these strains were identified as $P$. syringae pv. syringae (8).

MIC values for copper sulfate were determined for the $117 P$. syringae pv. syringae strains (Table 3 ), and those growing on

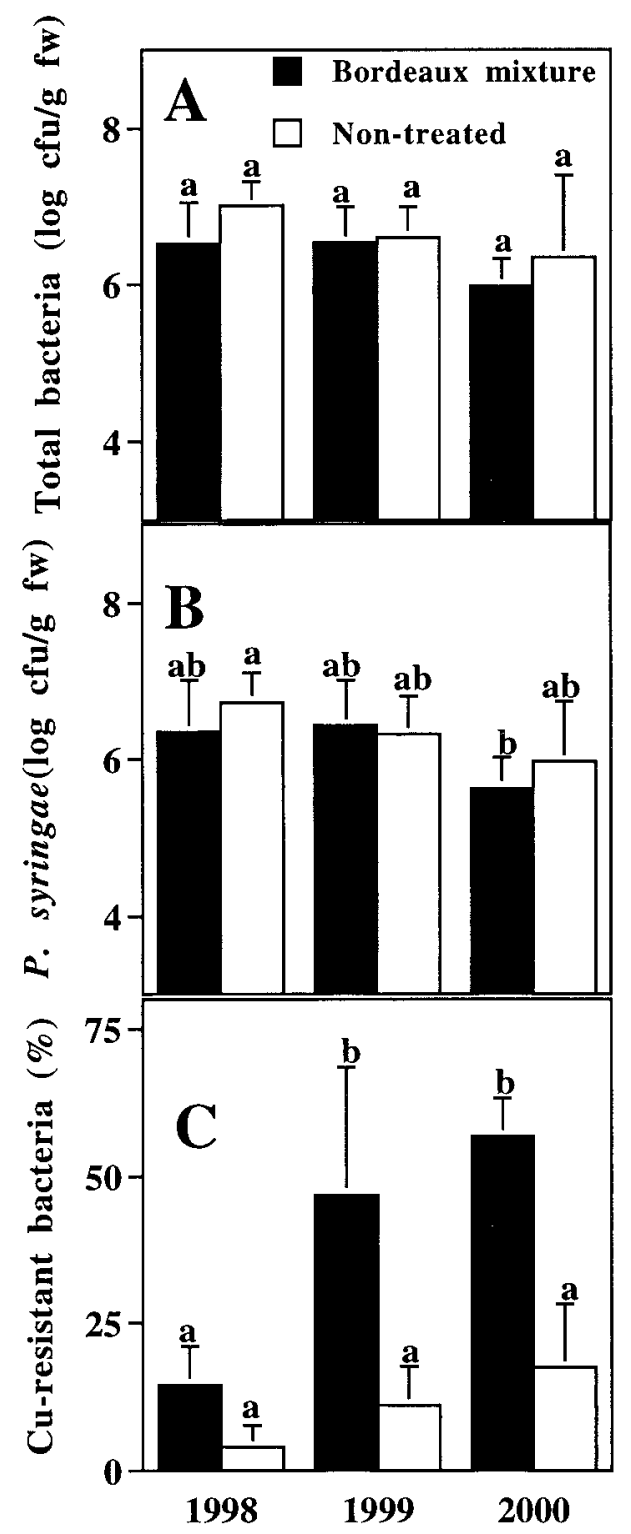

Fig. 1. Populations of A, total, B, Pseudomonas syringae-like, and $\mathbf{C}$, copper-resistant bacteria on buds of mango trees untreated or treated with Bordeaux mixture. Two groups of 12 trees each were sampled in February, April, and June, from 1998 to 2000: $\square=$ Nontreated trees; $\mathbf{\square}=$ trees subjected since September 1997 to a monthly spray of Bordeaux mixture ( $3 \mathrm{~g} /$ liter). Bulked samples of five buds were analyzed for each tree. The proportion of copper-resistant bacteria is the percentage of colonies obtained in mannitol-glutamate-yeast extract medium $+0.8 \mathrm{mM} \mathrm{CuSO}_{4}$ with respect to the total bacterial population. Population or percentage values shown in the figure represent the arithmetical mean of the values obtained on each sampling date plus the standard deviation. Means followed by the same letter (in each bar) are not significantly different according to least significant difference test $(P=0.01)$. 
MGY medium with $0.8 \mathrm{mM} \mathrm{CuSO}_{4}$ were considered to be resistant to copper $\left(\mathrm{Cu}^{\mathrm{r}}\right) . \mathrm{Cu}^{\mathrm{r}}$ strains were isolated from all of the mango orchards studied, from healthy as well as from diseased trees, and on average represented $59 \%$ of the total number of strains. Their MIC values varied between 1.0 and $3.2 \mathrm{mM} \mathrm{CuSO}_{4}$ (Table 3), although most of the strains had an MIC of $1.8 \mathrm{mM}$.

Plasmid analysis and characterization. Copper-resistance determinants in phytopathogenic bacteria are commonly associated with plasmids. Plasmid occurrence, therefore, was examined by agarose gel electrophoresis of DNA from $70\left(40 \mathrm{Cu}^{\mathrm{r}}\right.$ and $\left.30 \mathrm{Cu}^{\mathrm{s}}\right)$ randomly selected $P$. syringae pv. syringae mango isolates. Results are summarized in Table 4, and the plasmid profiles of strains representing the different patterns observed are shown in Figure 2A. Plasmids were detected in 52 of the strains by electrophoresis in agarose gels; 5 additional strains, all $\mathrm{Cu}^{\mathrm{r}}$, harbored a $120-\mathrm{kb}$ plasmid that was barely detectable on agarose gels and could be made readily apparent only in Southern blot hybridization experiments with the $\operatorname{cop} A B C D$ probe (Fig. 2, lane 11). Overall, there was no obvious correlation between plasmid sizes and resistance phenotype or the place of isolation. Only 3 of the $\mathrm{Cu}^{\mathrm{r}}$

TABLE 3. Number of Pseudomonas syringae pv. syringae strains isolated from mango trees, belonging to different categories of minimal inhibitory concentration (MIC) values for cupric sulfate (mM)

\begin{tabular}{|c|c|c|c|c|c|}
\hline \multirow[b]{3}{*}{ Place of isolation } & \multicolumn{4}{|c|}{ MIC (mM) interval for cupric sulfate } & \multirow[b]{3}{*}{ Total } \\
\hline & \multirow{2}{*}{$\frac{\text { Sensitive }}{<0.8}$} & \multicolumn{3}{|c|}{ Resistant } & \\
\hline & & $1.0-1.6$ & $1.8-2.4$ & $2.6-3.2$ & \\
\hline \multicolumn{6}{|l|}{ Spain } \\
\hline \multicolumn{6}{|l|}{ Málaga } \\
\hline Algarrobo & 10 & 8 & 19 & 3 & 40 \\
\hline Benajarafe & 7 & 1 & 1 & $\ldots$ & 9 \\
\hline Churriana & $\ldots$ & $\ldots$ & 4 & $\ldots$ & 4 \\
\hline Estepona & 1 & 2 & $\ldots$ & $\ldots$ & 3 \\
\hline Torrox & $\ldots$ & $\ldots$ & 2 & $\ldots$ & 2 \\
\hline \multicolumn{6}{|l|}{ Huelva } \\
\hline Lepe & 16 & $\ldots$ & 3 & 2 & 21 \\
\hline La Redondela & 7 & 3 & 4 & 5 & 19 \\
\hline \multicolumn{6}{|l|}{ Portugal } \\
\hline Faro & 7 & 5 & 7 & & 19 \\
\hline Total & 48 & 19 & 40 & 10 & 117 \\
\hline
\end{tabular}

strains were plasmidless, whereas 37 harbored plasmids, and 31 of them contained a $62-\mathrm{kb}$ plasmid, either alone or together with other plasmids. A 62-kb plasmid was widely distributed among the $\mathrm{Cu}^{\mathrm{s}}$ isolates, being present in 20 of them, although it did not show hybridization with the copper-resistance genes (copABCD) from $P$. syringae pv. tomato PT23, unlike the $62-\mathrm{kb}$ plasmid present in $\mathrm{Cu}^{\mathrm{r}}$ isolates (Fig. 2B). No plasmids were apparent in the 10 other $\mathrm{Cu}^{\mathrm{s}}$ strains. According to plasmid content and the pattern of hybridization to the $\operatorname{cop} A B C D$ probe, the 70 strains examined could be assigned to six different plasmid profile groups (Table 4).

Different $62-\mathrm{kb}$ plasmids were subjected to restriction analysis with EcoRI to compare the plasmids harbored by $\mathrm{Cu}^{\mathrm{r}}$ strains with those present in $\mathrm{Cu}^{\mathrm{s}}$ strains. Plasmids were purified from the 24 $\mathrm{Cu}^{\mathrm{r}}$ isolates assigned to plasmid profile II, the $20 \mathrm{Cu}^{\mathrm{s}}$ isolates assigned to profile VI, and from derivatives of the $6 \mathrm{Cu}^{\mathrm{r}}$ isolates from profile I, which were obtained by curing their $88-\mathrm{kb}$ plasmid as described above. Among the 50 strains studied, the $62-\mathrm{kb}$ plasmids could be classified in five different EcoRI restriction patterns (Fig. 3, Table 4), which were designated 62.1 to 62.5. Consequently, plasmid profile groups II and VI included strains which harbored different plasmids, although they were indistinguishable by electrophoresis on agarose gels. Two of the restriction patterns (62.1 and 62.2) were exclusively present in $\mathrm{Cu}^{\mathrm{r}}$ strains, and two other patterns were detected only in $\mathrm{Cu}^{\mathrm{s}}$ strains (62.4 and 62.5). Only one of the patterns (62.3) was observed in $\mathrm{Cu}^{\mathrm{r}}$ as well as in $\mathrm{Cu}^{\mathrm{s}}$ strains, although the 62.3-type plasmids could be differentiated by their pattern of hybridization to a probe containing copper-resistance genes; thus, the hybridizing patterns designated as $62.3 \mathrm{a}$ and $62.3 \mathrm{~b}$ were associated with $\mathrm{Cu}^{\mathrm{r}}$ strains that hybridize with $\operatorname{cop} A B C D$ probe, whereas the nonhybridizing pattern $(62.3 \mathrm{c})$ was exclusively present in $\mathrm{Cu}^{\mathrm{s}}$ strains. The plasmid types 62.2 $\left(\mathrm{Cu}^{\mathrm{r}}\right)$ and $62.5\left(\mathrm{Cu}^{\mathrm{s}}\right)$ differed only by specific bands of 19.7 and $2.5 \mathrm{~kb}$, respectively (Fig. 3, lanes 2 and 6). The final size, obtained by adding up all the restriction fragments in each plasmid pattern (Fig. 3), suggested the presence of repeated bands below $7 \mathrm{~kb}$ for all the 62.3-type plasmids (lanes 3 and 4). The most frequently found plasmid type was 62.1 , which was carried by 23 strains isolated from two locations in Málaga, Spain, and from one location in Portugal (Table 4). On the other hand, plasmid 62.2 and those of plasmid profiles IV and V had a very limited distri-

TABLE 4. Number of copper-resistant $\left(\mathrm{Cu}^{\mathrm{r}}\right)$ and copper-sensitive $\left(\mathrm{Cu}^{\mathrm{s}}\right)$ Pseudomonas syringae pv. syringae strains belonging to different plasmid profile groups $^{t}$

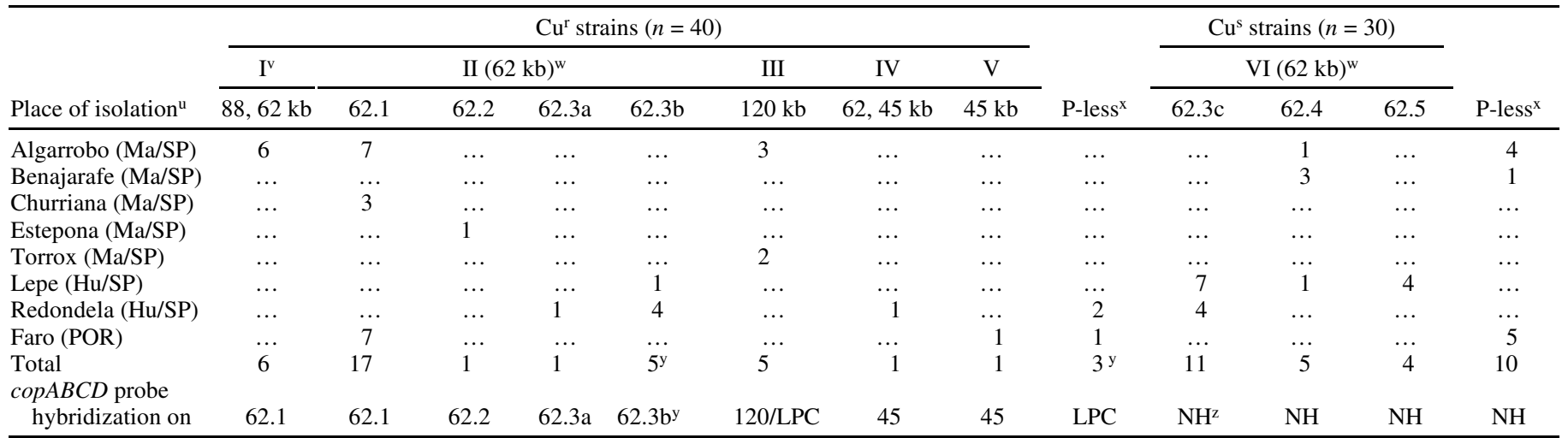

${ }^{\mathrm{t}}$ The size of the plasmids on each plasmid profile group is indicated in parenthesis. The 40 copper-resistant and 30 copper-sensitive strains were randomly chosen from a collection of 117 strains isolated from mango trees in different locations of Spain and Portugal. The hybridization of these strains with the copABCD operon probe also are summarized.

" Ma/SP = Málaga, Spain; Hu/SP = Huelva, Spain; and POR = Portugal.

$\checkmark$ The $62-\mathrm{kb}$ plasmid from profile I is 62.1 type.

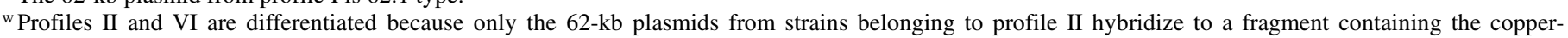
resistance genes copABCD. For profiles II and VI, numbers 62.1 to 62.5 indicate 62 -kb plasmids, which are differentiated by their restriction profile with $E c o$ RI or, in the case of the 62.3 (a to c), by their hybridization to the $c o p A B C D$ probe.

$\times$ P-less $=$ plasmidless.

${ }^{y}$ In these strains, 62-kb plasmid or linearized plasmid and chromosomal DNA (LPC) hybridized with copABCD only at low stringency conditions. The rest of the copper-resistant strains showed positive hybridization at high stringency conditions.

${ }^{\mathrm{z}} \mathrm{NH}=$ these strains did not hybridize with $\operatorname{cop} A B C D$ probe either at high- or low-stringency conditions. 
bution and were represented in each case by only a single strain (Table 4).

Detection of homology to cop probes. Southern blot analyses of intact plasmids and digested plasmid and genomic DNA were performed (Figs. 2, 4, and 5, Table 4) to determine whether the $\mathrm{Cu}^{\mathrm{r}}$ P. syringae pv. syringae isolates from mango contained DNA homologous to the previously described copper-resistance genes copABCD from $P$. syringae pv. tomato PT23 (4) and copJ from $P$. syringae pv. syringae AL513 (28). The previously selected 70 isolates $\left(40 \mathrm{Cu}^{\mathrm{r}}\right.$ and $\left.30 \mathrm{Cu}^{\mathrm{s}}\right)$ were examined. A total of $32 \mathrm{Cu}^{\mathrm{r}}$ strains contained plasmids that showed moderate to strong crosshybridization to the $\operatorname{cop} A B C D$ probe under high-stringency hybridization conditions (Table 4). Hybridization signals were observed for all the 62.1 plasmids, the 62.2 plasmid, one of the 62.3 plasmids (62.3a), the $120-\mathrm{kb}$ plasmids, and the $45-\mathrm{kb}$ plasmids (Fig. 2B, lanes 2 to 11). The 62.2 plasmid from the strain UMAF0170 had a stronger hybridization signal than the other tested strains. Additionally, the band corresponding to linear plasmid and chromosomal DNA also showed hybridization to the probe for strains containing 120-kb plasmids (Fig. 2, lane 11).

Analysis of plasmid and genomic DNA digested with EcoRI (Fig. 4, Table 4) revealed that the DNA homologous to the probe was located in a 19.7-kb fragment for all the plasmids of patterns $62.1,62.2$, and 62.3a; a 15-kb fragment for the 45-kb plasmid from profile IV; and a $12.7-\mathrm{kb}$ fragment for $120-\mathrm{kb}$ plasmids and the $45-\mathrm{kb}$ plasmid from profile V (lanes 2-11). Thus, the 19.7-kb fragment seems to be common to many $62-\mathrm{kb}$ plasmid groups (Fig. 3). Genomic DNA from strains harboring the $120-\mathrm{kb}$ plasmids showed an additional hybridizing band of $19.7 \mathrm{~kb}$, suggesting the occurrence of an extra copy of $\operatorname{cop} A B C D$ homologues in chromosomal DNA or the detection of an additional plasmid fragment not detected previously. Chromosomal DNA of the three plasmidless $\mathrm{Cu}^{\mathrm{r}}$ isolates and plasmids of 62.3-type from the remaining five $\mathrm{Cu}^{\mathrm{r}}$ strains (designated as 62.3b) showed hybridization to the copABCD probe under low-stringency conditions $\left(42^{\circ} \mathrm{C}\right)$ but not under high-stringency conditions $\left(65^{\circ} \mathrm{C}\right)$ (Figs. 2 and 5 , lanes 7 and 12). No hybridizing bands were observed under

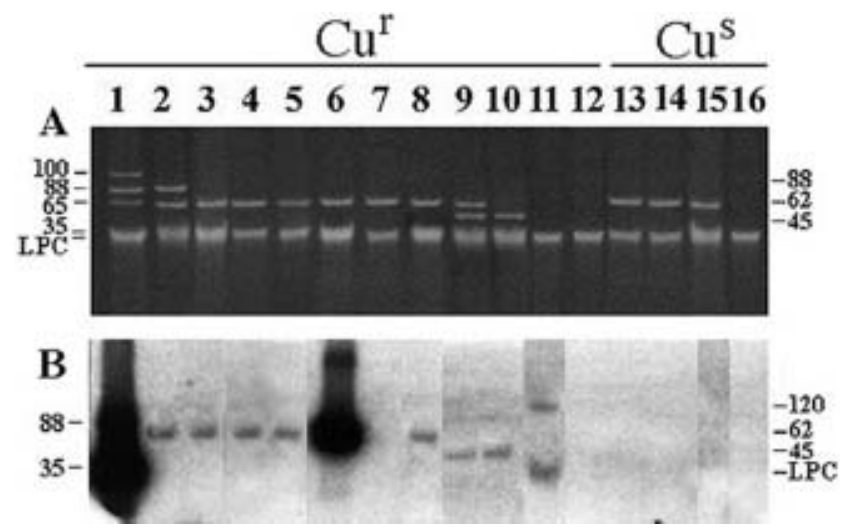

Fig. 2. Hybridization of intact native plasmids from 15 representative Pseudomonas syringae pv. syringae strains isolated from mango trees with a probe containing the copper-resistance genes cop $A B C D$. A, Agarose gel electrophoresis showing the different profiles detected. B, Southern blot analysis under high -stringency conditions of the gel shown in A using the 4.4-kb Pst I fragment containing the copABCD operon from $P$. syringae pv. tomato PT23 as a probe. Lane 1: $P$. syringae pv. tomato PT23 (used as molecular size marker and hybridization control). P. syringae pv. syringae isolates from mango trees are in lanes (plasmid profiles and the type of 62-kb plasmid harbored are indicated in parenthesis) 2, UMAF0049 (I, 62.1); 3, UMAF0081 (II, 62.1); 4, UMAF2016 (II, 62.1); 5, UMAF1012 (II, 62.1); 6, UMAF 0170 (II, 62.2); 7, UMAF1065 (II, 62.3b); 8, UMAF1110 (II, 62.3a); 9, UMAF1128 (IV); 10, UMAF2026 (V); 11, UMAF0167 (III); 12, UMAF2025 (plasmidless); 13, UMAF1094 (VI, 62.3c); 14, UMAF0158 (VI, 62.4); 15, UMAF1029 (VI, 62.5); 16, UMAF0174 (plasmidless). $\mathrm{Cu}^{\mathrm{r}}=$ copper-resistant strains and $\mathrm{Cu}^{\mathrm{s}}=$ copper-sensitive strains. Plasmids size $(\mathrm{kb})$ are listed at left and right. LPC indicates linear plasmid and chromosomal DNA. high- or low-stringency conditions with plasmid or chromosomal DNA from the $30 \mathrm{Cu}^{\mathrm{s}}$ strains, including the strains with the $62-\mathrm{kb}$ plasmids and 62.3c pattern (Figs. 2, 4 and 5, lanes 13-16; Table 4). These results revealed the presence of DNA homologous to the cop $A B C D$ operon in all the examined $\mathrm{Cu}^{\mathrm{r}}$ strains of $P$. syringae but in none of the $\mathrm{Cu}^{\mathrm{s}}$ strains.

No hybridization bands were observed with any of the $40 \mathrm{Cu}^{\mathrm{r}}$ and $30 \mathrm{Cu}^{\mathrm{s}}$ isolates tested using the 2.8-kb BamHI-PstI fragment containing copJ as a probe, either at high- or low-stringency hybridization conditions (data not shown).

Conjugation assays. The curing and mobilization of different $62-\mathrm{kb}$ plasmids was attempted in order to confirm if the observed homology with the $\operatorname{cop} A B C D$ probe was indeed identifying the genes responsible for the $\mathrm{Cu}^{\mathrm{r}}$ phenotype of their harboring strains. Curing of the plasmids was unsuccessful using conventional treatments, such as growth with ethidium bromide or acridine orange, or by incompatibility with the related pPT23A origin of replication included in pAKC (6). When strains UMAF0081 and UMAF0049c4, both containing 62.1 plasmids, were mated with FF5-km, copper resistance was transferred to FF5-km at frequencies ranging from $1.4 \times 10^{-6}$ to $1.0 \times 10^{-7}$. No spontaneous $\mathrm{Cu}^{\mathrm{r}}$ mutants were recovered in control platings of recipient cells alone. The MIC for copper sulfate for purified transconjugants from independent matings was $1.8 \mathrm{mM}$, the same determined for the donor strains, and all of them contained a plasmid that was indistinguishable from the 62.1 plasmid type on agarose gels (data not shown). Despite numerous attempts, we were unable to obtain $\mathrm{Cu}^{\mathrm{r}}$ transconjugants of FF5-km using UMAF0170, which harbors a 62.2 plasmid, as donor strain.

\section{DISCUSSION}

Bacterial apical necrosis of mango (Mangifera indica L.), incited by $P$. syringae pv. syringae is one of the principal diseases

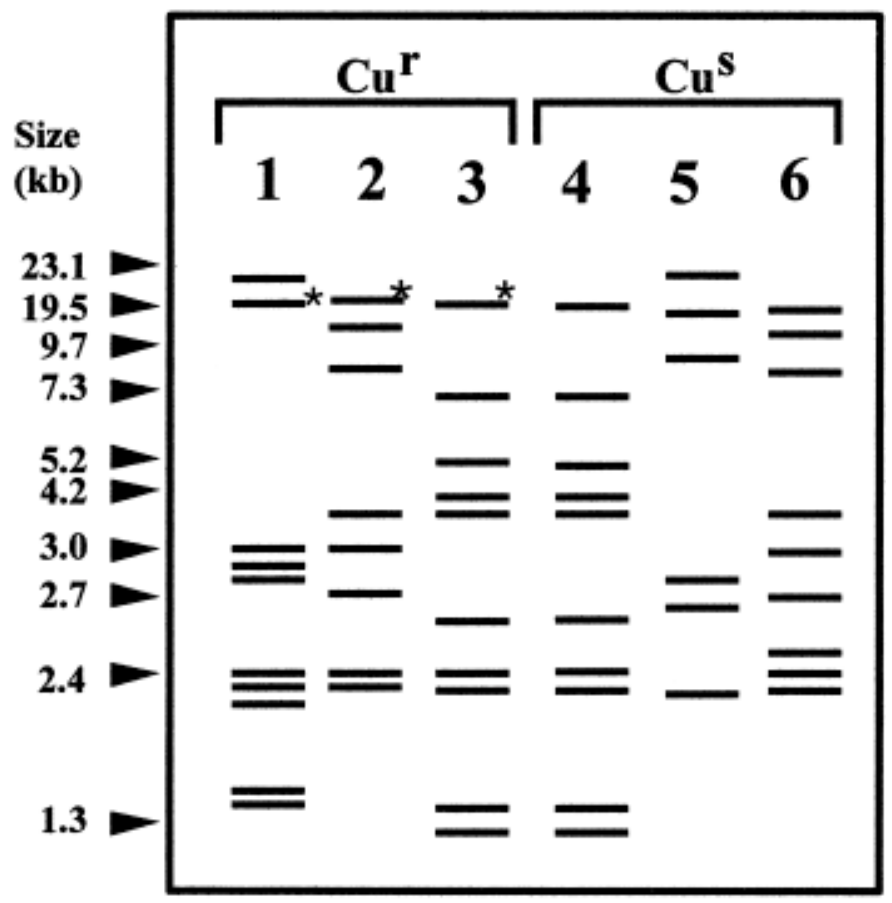

Fig. 3. Graphic representation of the six different EcoRI restriction patterns observed among the 62-kb plasmids from copper-resistant (patterns 1 to 3 ) and copper-sensitive (patterns 4 to 6) Pseudomonas syringae pv. syringae strains. The patterns are designated as 62.1 (1); 62.2 (2); 62.3a and 62.3b (3); $62.3 \mathrm{c}(4) ; 62.4$ (5), and 62.5 (6). Asterisks indicate fragments from 62.1, 62.2 , and $62.3 \mathrm{a}$ patterns hybridizing at high stringency to a probe containing the copper-resistance genes copABCD. Molecular weight $(\mathrm{kb})$ of linear DNA size standards is indicated at left. 
which limits mango fruit production in orchards along the Southern coast of the Iberian peninsula (8). After a few years of treatment, growers have noticed a reduction in efficacy of copper compounds for the control of apical necrosis (8); our results suggest that the build-up of a $\mathrm{Cu}^{\mathrm{r}} P$. syringae pv. syringae population is responsible, at least in part, for the increased disease control failures. We isolated $\mathrm{Cu}^{\mathrm{r}} P$. syringae pv. syringae from all the sampled mango orchards in southern Spain and Portugal, where copper-based bactericides have been used for several years. Additionally, we have shown that repeated treatments with Bordeaux mixture on a commercial orchard could be correlated with a significant increase in the $\mathrm{Cu}^{\mathrm{r}}$ bacterial population (Fig. 1). These data conclusively confirm that the extensive use of copper-based bactericides favors the occurrence of bacterial copper resistance $(3,37)$, which may explain control failures following treatments with copper compounds $(1,13,30,35,39)$. However, the overall proportion of $\mathrm{Cu}^{\mathrm{r}}$ bacteria never was higher than approximately $60 \%$, so that $\mathrm{Cu}^{\mathrm{s}}$ populations might be due to bacteria colonizing areas of the trees that are not reached by the bactericides. In fact, it was previously shown (8) that buds of infested mango trees harbor a high population of $P$. syringae pv. syringae year round, and it is possible that bud architecture allows population pockets that are effectively shielded from harsh environmental conditions. This suggests that, in those cases where the bacteria already have colonized the buds internally, chemical control of bacterial apical necrosis using nonsystemic products would be only partially successful, even if the bacterial population is susceptible to the bactericide used.

All the $\mathrm{Cu}^{\mathrm{r}}$ strains examined hybridized, either at high- (32 strains) or low-stringency conditions (8 strains), to a DNA fragment containing the structural genes for copper resistance (copABCD) from $P$. syringae pv. tomato PT23 (Figs. 2, 4, and 5), but not to a fragment containing the copper-resistance locus copJ from $P$. syringae AL513; therefore, $\operatorname{cop} A B C D$ homologous sequences could be involved in the observed copper resistance of $P$. syringae strains of mango. Copper-resistance determinants related to the copABCD operon have been described in recent years from different genera of bacteria in agricultural environments where copper compounds are applied $(12,19,28,31,42,43)$. As expected, the $\mathrm{Cu}^{\mathrm{s}}$ strains did not hybridize to any of the probes, either at high- or low-stringency conditions. The $40 \mathrm{Cu}^{\mathrm{r}} P$. syringae pv. syringae isolates examined were genetically very diverse, as judged by the multiplicity of plasmid profiles, the location of the putative copper-resistance genes, and the intensity of their hybridization to the $\operatorname{cop} A B C D$ probe, and could be classified into nine different groups (Table 4). This diversity appears to be reflected in the population structure of infested orchards: in those places where eight or more $\mathrm{Cu}^{\mathrm{r}}$ isolates were obtained, they could be classified into three or more different genotypic groups (Table 4). However, it appears that certain $\mathrm{Cu}^{\mathrm{r}}$ and $\mathrm{Cu}^{\mathrm{s}}$ genotypes could be associated with specific geographical areas; for instance, the 62.3type plasmids were found only in areas of Huelva. Nonetheless, and given the limited number of isolates tested, it would be necessary to examine more isolates to confirm this observation. Our results, therefore, might suggest that the emergence of copper resistance in the mango orchards studied could be due to the selection of local resistant genotypes rather than to the distribution of one or a few $\mathrm{Cu}^{\mathrm{r}}$ genotypes in infested plant material. However, the isolation of $\mathrm{Cu}^{\mathrm{r}}$ strains harboring 62.1 plasmids from orchards of Spain and Portugal, separated by up to $400 \mathrm{~km}$, indicates that some of these bacteria might originate from nurseries propagating contaminated plants (39). In fact, $P$. syringae pv. syringae has, in general, a wide host range (23), and isolates from mango were indeed shown to be pathogenic to several other trees and herbaceous plants (8). Although this is, to our knowledge, the first report of $\mathrm{Cu}^{\mathrm{r}}$ bacteria in Spain and Portugal, it is possible that the use of copper bactericides in other crops has allowed the selection and maintenance of $\mathrm{Cu}^{\mathrm{r}}$ P. syringae pv. syringae populations (31) that could have subsequently colonized mangoes.

A much more intense hybridization of the cop probe to the 62-kb plasmid of strain UMAF0170 was observed; this suggests that the copper-resistance determinant of this strain is more closely related to the cop genes of $P$. syringae pv. tomato PT23. The $\mathrm{Cu}^{\mathrm{r}}$ genetic determinants described here were also diverse, as judged by the intensity of their hybridization signals with the cop $A B C D$ probe, which were moderately or very intense under
$\mathrm{Cu}^{\mathrm{r}} \mathrm{Cu}^{\mathrm{S}}$

\section{6}

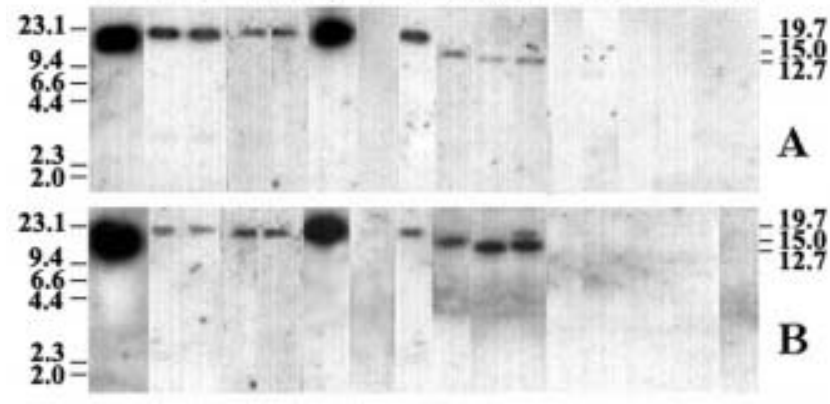

Fig. 4. Southern hybridization of A, EcoRI-digested plasmid DNA and B, total genomic DNA from 15 representative Pseudomonas syringae pv. syringae strains isolated from mango trees using the 4.4-kb PstI fragment containing the copper-resistance genes copABCD from $P$. syringae pv. tomato PT23. $\mathrm{Cu}^{\mathrm{r}}=$ copper-resistant strains and $\mathrm{Cu}^{\mathrm{s}}=$ copper-sensitive strains. Lane 1: P. syringae pv. tomato PT23 (used as molecular size marker and hybridization control). $P$. syringae pv. syringae isolates from mango trees are in lanes (plasmid profiles and the type of $62-\mathrm{kb}$ plasmid harbored are indicated in parenthesis) 2, UMAF0049 (I, 62.1); 3, UMAF0081 (II, 62.1); 4, UMAF2016 (II, 62.1); 5, UMAF1012 (II, 62.1); 6, UMAF 0170 (II, 62.2); 7, UMAF1065 (II, 62.3b); 8, UMAF1110 (II, 62.3a); 9, UMAF1128 (IV); 10, UMAF2026 (V); 11, UMAF0167 (III); 12, UMAF2025 (plasmidless); 13, UMAF1094 (VI, 62.3c); 14, UMAF0158 (VI, 62.4); 15, UMAF1029 (VI, 62.5); 16, UMAF0174 (plasmidless). Molecular weight $(\mathrm{kb})$ of linear DNA size standards and hybridizing fragments are indicated at left and right, respectively.

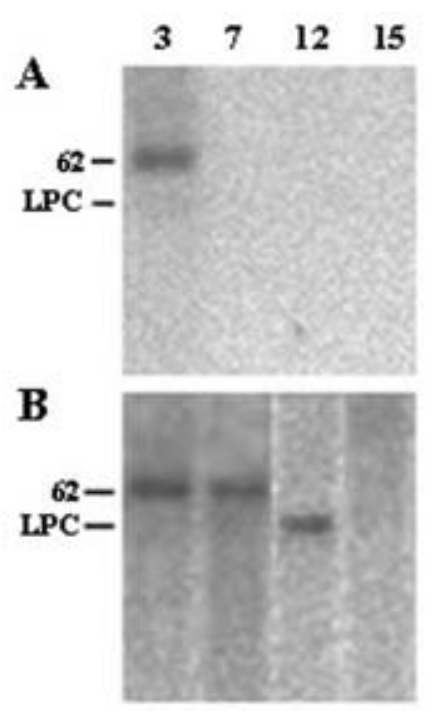

Fig. 5. Southern hybridization of plasmid profile gels of selected Pseudomonas syringae pv. syringae isolates with a probe containing the copperresistance genes cop $A B C D$. Hybridizations were carried out under A, highstringency and $\mathbf{B}$, low-stringency conditions. P. syringae pv. syringae isolates from mango trees are in lanes (plasmid profiles and the type of 62-kb plasmid harbored are indicated in parenthesis) 3, UMAF0081 (II, 62.1); 7, UMAF1065 (II, 62.3b); 12, UMAF2025 (plasmidless); and 15, UMAF1029 (VI, 62.5). The size of the hybridizing plasmids $(62 \mathrm{~kb})$ is marked at left. LPC indicates linear plasmid and chromosomal DNA. 
high-stringency hybridization conditions or only apparent under low-stringency conditions (Figs. 2 and 5). These differences in hybridization are not likely to be due to the presence of mobile elements, because the probe contains only approximately $100 \mathrm{nt}$ on either side of the open reading frames of the $\operatorname{cop} A B C D$ operon; the differences probably reflect different levels of homology or the conservation of only part of the $\mathrm{Cu}^{\mathrm{r}}$ determinant. This last possibility is the most likely, because copper-resistance determinants that are only partially homologous to the $\operatorname{cop} A B C D$ genes from strain PT23 already have been described in other bacteria, such as P. syringae pv. actinidae (M. Nakajima, accession no. AB033419) and Ralstonia metallidurans (B. Borremans and D. van der Lelie, accession no. AJ278983). The diversity of copper-resistance determinants among $P$. syringae pv. syringae colonizing mango is intriguing, and suggests that they might play another role in bacterial metabolism, being selected for under the strong selective pressure of a copper-enriched environment. This is not unlikely; for example, Aeromonas veronii biovar sobria 3767, a pathogen of humans, carries a homologue of $\operatorname{cop} A B C D$ that is required for tolerance to copper as well as for adhesion to cultured epithelial human cells (16). The oxidase activities recently described for CopA-related proteins is another example (33). Similarly, an unrelated set of copper-resistance genes from $P$. fluorescens is involved in cytochrome $c$ biogenesis and competitive fitness (43). The previously reported presence of cop homologues in coppersensitive Pseudomonas strains $(10,12)$ further supports the involvement of the cop homologues from $P$. syringae pv. syringae in other cellular functions.

Several plasmid profiles were observed in the $P$. syringae isolates, but a $62-\mathrm{kb}$ plasmid was the most frequently detected, both in $\mathrm{Cu}^{\mathrm{r}}$ and $\mathrm{Cu}^{\mathrm{s}}$ strains (72.9\%). In $\mathrm{Cu}^{\mathrm{r}}$ isolates harboring this plasmid, copABCD homologues generally were associated with it. Plasmidic copper resistance has been reported in many phytopathogenic bacteria $(3,5,10,11,35,39,42)$. Furthermore, all of the $62-\mathrm{kb}$ plasmids cross-hybridized to the origin of replication from pPT23A (6), therefore belonging to the recently described pPT23Alike family (17), and to the rulAB genes (6), which confer tolerance to ultraviolet radiation $(38,40,41)$. Thus, copper-resistance determinants may have been incorporated into the bacterial population along with other plasmid-encoded traits that could enhance the ecological fitness and persistence of their harboring strains $(15,20)$. In fact, plasmids of the pPT23A-like family tend to encode determinants of importance for the ecology of diverse $P$. syringae pathovars, such as avirulence, extracellular virulence factors, and resistance to antibiotics $(18,32,36)$. Additionally, it is important to note that mango plant surfaces are exposed to heavy solar radiation in southern Europe; it is conceivable that plasmidencoded traits such as UV radiation tolerance could contribute to the maintenance of the carrying plasmid and, consequently, of any other genes that might be on the plasmid.

In contrast to our results, other authors have reported a strong conservation of $\mathrm{Cu}^{\mathrm{r}}$ determinants among $\mathrm{Cu}^{\mathrm{r}}$ bacteria isolated from the same field and from areas as distant from one another as California and Florida; albeit, in certain instances, the determinants were located on dissimilar plasmids $(5,9,10,12,36)$. These bacteria, unlike $P$. syringae pv. syringae, were primarily narrowhost-range pathogens. The variety of habitats (mainly plants) that $P$. syringae pv. syringae may encounter could increase the diversity of its copper-resistance determinants. $\mathrm{Cu}^{\mathrm{r}}$ determinants often are associated with conjugative or mobilizable plasmids $(10,26$, 34,42). Also, $\mathrm{Cu}^{\mathrm{r}}$ genes located on the $X$. axonopodis pv. vesicatoria (formerly $X$. campestris) (2) chromosome were shown to be transferred by conjugation, which supports the idea that their evolutionary success could be related to their capacity to reach a large number of bacteria through horizontal exchange $(35,39)$. Plasmid-borne determinants are in general more easily established in bacterial populations (15) and the apparent prevalence of 62.1 plasmids might be due to its conjugative ability. It is possible, that the current structure of the $\mathrm{Cu}^{\mathrm{r}}$ population in mango orchards represents an early evolutionary phase that could change toward the predominance of a single, more fit, copper-resistance determinant.

\section{ACKNOWLEDGMENTS}

This work was partially supported by grants from Plan Nacional de I+D (AGF98-0931-C02-01 and AGF98-0402-C03-03) and Consejería de Agricultura y Pesca, Junta de Andalucía. F. Cazorla thanks the Universidad de Málaga for a fellowship covering a short stay in the Universidad Pública de Navarra. We thank C. Bender, V. de Lorenzo, S. Lindow, and G. W. Sundin for kindly providing us with some of the bacterial strains and DNA probes used in this study; G. W. Sundin and A. Vivian for critical reading of the manuscript and helpful suggestions; and J. M. Farré, L. Velasco, F. Olea, and D. del Pino for their assistance during the course of some experiments.

\section{LITERATURE CITED}

1. Andersen, G. L., Menkissoglou, O., and Lindow, S. E. 1991. Occurrence and properties of copper-tolerant strains of Pseudomonas syringae isolated from fruit trees in California. Phytopathology 81:648-656.

2. Basim, H., Stall, R. E., Minsavage, G. V., and Jones, J. B. 1999. Chromosomal gene transfer by conjugation in the plant pathogen Xanthomonas axonopodis pv. vesicatoria. Phytopathology 89:1044-1049.

3. Bender, C., and Cooksey, D. 1986. Indigenous plasmids in Pseudomonas syringae pv. tomato: Conjugative transfer and role in copper resistance. J. Bacteriol. 165:534-541.

4. Bender, C. L., and Cooksey, D. A. 1987. Molecular cloning of copper resistance genes from Pseudomonas syringae pv. tomato. J. Bacteriol. 169:470-474.

5. Bender, C. L., Malvick, D. K., Conway, K. E., George, S., and Pratt, P. 1990. Characterization of pXV10A, a copper resistance plasmid in Xanthomonas campestris pv. vesicatoria. Appl. Environ. Microbiol. 56:170175.

6. Cazorla, F. M. 1998. Pseudomonas syringae pv. syringae, agente causal de la necrosis apical del mango. Ecología y caracterización bacteriológica y molecular. Ph.D. thesis. Universidad de Málaga, Spain.

7. Cazorla, F. M., Olalla, L., Torés, J. A., Codina, J. C., Pérez-García, A., and de Vicente, A. 1997. Pseudomonas syringae pv. syringae as microorganism involved in apical necrosis of mango: Characterization of some virulence factors. Pages 82-87 in: Pseudomonas syringae Pathovars and Related Pathogens. K. Rudolph, T. J. Burr, J. W. Mansfield, D. Stead, A. Vivian, and J. von Kietzell, eds. Kluwer Academic Publishers, Dordrecht, the Netherlands.

8. Cazorla, F. M., Torés, J. A., Olalla, L., Pérez-García, A., Farré, J. M., and de Vicente, A. 1998. Bacterial apical necrosis of mango in southern Spain: A disease caused by Pseudomonas syringae pv. syringae. Phytopathology 88:614-620.

9. Cooksey, D. A. 1987. Characterization of a copper resistance plasmid conserved in copper-resistant strains of Pseudomonas syringae pv. tomato. Appl. Environ. Microbiol. 53:454-456.

10. Cooksey, D. A. 1990. Genetics of bactericide resistance in plant pathogenic bacteria. Annu. Rev. Phytopathol. 28:201-219.

11. Cooksey, D. A. 1990. Plasmid-determined copper resistance in Pseudomonas syringae from impatiens. Appl. Environ. Microbiol. 56:13-16.

12. Cooksey, D. A., Azad, H. R., Cha, J.-S., and Lim, C.-K. 1990. Copper resistance gene homologs in pathogenic and saprophytic bacterial species from tomato. Appl. Environ. Microbiol. 56:431-435.

13. Cuppels, D. A., and Elmhirst, J. 1999. Disease development and changes in the natural Pseudomonas syringae pv. tomato populations on field tomato plants. Plant Dis. 83:759-764.

14. de Lorenzo, V., and Timmis, K. N. 1994. Analysis and construction of stable phenotypes in Gram-negative bacteria with Tn5 and Tn10-derived mini-transposons. Methods Enzymol. 235:386-415.

15. Eberhard, W. G. 1989. Why do bacterial plasmids carry some genes and not others? Plasmid 21:167-174.

16. Francki, K. T., Chang, B. J., Mee, B. J., Collignon, P. J., Susai, V., and Keese, P. K. 2000. Identification of genes associated with copper tolerance in an adhesion-defective mutant of Aeromonas veronii biovar sobria. FEMS Immunol. Med. Microbiol. 29:115-121.

17. Gibbon, M. J., Sesma, A., Canal, A., Wood, J. R., Hidalgo, E., Brown, J., Vivian, A., and Murillo, J. 1999. Replication regions from plant-pathogenic Pseudomonas syringae plasmids are similar to ColE2-related replicons. Microbiology 145:325-334.

18. Jackson, R. W., Athanassopoulos, E., Tsiamis, G., Mansfield, J. W., Sesma, A., Arnold, D. L., Gibbon, M. J., Murillo, J., Taylor, J. D., and 
Vivian, A. 1999. Identification of a pathogenicity island, which contains genes for virulence and avirulence, on a large native plasmid in the bean pathogen Pseudomonas syringae pathovar phaseolicola. Proc. Natl. Acad. Sci. USA 96:10875-10880.

19. Lee, Y.-A., Hendson, M., Panopoulos, N., and Schroth, M. N. 1994. Molecular cloning, chromosomal mapping, and sequence analysis of copper resistance genes from Xanthomonas campestris pv. juglandis: Homology with small blue copper proteins and multicopper oxidase. J. Bacteriol. 176:173-188.

20. Levin, B. R., and Bergstrom, C. T. 2000. Bacteria are different: Observations, interpretations, speculations, and opinions about the mechanisms of adaptive evolution in prokaryotes. Proc. Natl. Acad. Sci. USA 97:6981-6985.

21. Lim, C.-K., and Cooksey, D. A. 1993. Characterization of chromosomal homologs of the plasmid-borne copper resistance operon of Pseudomonas syringae. J. Bacteriol. 175:4492-4498.

22. Litz, R. E., ed. 1997. The Mango: Botany, Production and Uses. CAB International, Wallingford, UK.

23. López, M. M., and Montesinos, E. 1996. Enfermedades causadas por bacterias fitopatógenas. Pages 515-558 in: Patología Vegetal, vol. I. G. Llácer, M. M. López, A. Trapero, and A. Bello, eds. SEF-Phytoma, Valencia, Spain.

24. Marco, G. M., and Stall, R. E. 1983. Control of bacterial spot of pepper initiated by strains of Xanthomonas campestris pv. vesicatoria that differ in sensitivity to copper. Plant Dis. 67:779-781.

25. Mellano, M. A., and Cooksey, D. A. 1988. Nucleotide sequence and organization of copper resistance genes from Pseudomonas syringae pv. tomato. J. Bacteriol. 170:2879-2883.

26. Murillo, J., and Keen, N. T. 1994. Two native plasmids of Pseudomonas syringae pathovar tomato strain PT23 share a large amount of repeated DNA, including replication sequences. Mol. Microbiol. 12:941-950.

27. Murillo, J., Shen, H., Gerhold, D., Sharma, A. K., Cooksey, D. A., and Keen, N. T. 1994. Characterization of pPT23B, the plasmid involved in syringolide production by Pseudomonas syringae pv. tomato. Plasmid 31:275-287.

28. Rogers, J. S., Clark, E., Cirvilleri, G., and Lindow, S. E. 1994. Cloning and characterization of genes conferring copper resistance in epiphytic ice nucleation-active Pseudomonas syringae strains. Phytopathology 84:891-897.

29. Sambrook, J., Fritsch, E. F., and Maniatis, T. 1989. Molecular Cloning: A Laboratory Manual. 2nd ed. Cold Spring Harbor Laboratory, Cold Spring Harbor, NY.

30. Scheck, H. J., and Pscheidt, J. W. 1998. Effect of copper bactericides on copper-resistant and -sensitive strains of Pseudomonas syringae pv. syringae. Plant Dis. 82:397-406.

31. Scheck, H. J., Pscheidt, J. W., and Moore, L. W. 1996. Copper and streptomycin resistance in strains of Pseudomonas syringae from Pacific
Northwest nurseries. Plant Dis. 80:1034-1039.

32. Sesma, A., Aizpún, M. T., Ortiz, A., Arnold, D., Vivian, A., and Murillo, J. 2001. Virulence determinants other than coronatine in Pseudomonas syringae pv. tomato PT23 are plasmid-encoded. Physiol. Mol. Plant Pathol. 58:83-93.

33. Solano, F., Lucas-Elío, P., López-Serrano, D., Férnandez, E., and Sánchez-Amat, A. 2001. Dimethoxyphenol oxidase activity of different microbial blue multicopper proteins. FEMS Microbiol. Lett. 204:175181.

34. Stall, R. E., Loschke, D. C., and Jones, J. B. 1986. Linkage of copper resistance and avirulence loci on a self-transmissible plasmid in Xanthomonas campestris pv. vesicatoria. Phytopathology 76:240-243.

35. Sundin, G. W., and Bender, C. L. 1993. Ecological and genetic analysis of copper and streptomycin resistance in Pseudomonas syringae pv. syringae. Appl. Environ. Microbiol. 59:1018-1024.

36. Sundin, G. W., and Bender, C. L. 1996. Molecular analysis of closely related copper- and streptomycin-resistance plasmids in Pseudomonas syringae pv. syringae. Plasmid 35:98-107.

37. Sundin, G. W., Demezas, D. H., and Bender, C. L. 1994. Genetic and plasmid diversity within natural populations of Pseudomonas syringae with various exposures to copper and streptomycin bactericides. Appl. Environ. Microbiol. 60:4421-4431.

38. Sundin, G. W., Jacobs, J. L., and Murillo, J. 2000. Sequence diversity of rulA among natural isolates of Pseudomonas syringae and effect on the function of $r u l A B$-mediated UV radiation tolerance. Appl. Environ. Microbiol. 66:5167-5173.

39. Sundin, G. W., Jones, A. L., and Fulbright, D. W. 1989. Copper resistance in Pseudomonas syringae pv. syringae from cherry orchards and its associated transfer in vitro and in planta with a plasmid. Phytopathology 79:861-865.

40. Sundin, G. W., Kidambi, S. P., Ullrich, M., and Bender, C. L. 1996. Resistance to ultraviolet light in Pseudomonas syringae: Sequence and functional analysis of the plasmid-encoded rulAB genes. Gene 177:7781 .

41. Sundin, G. W., and Murillo, J. 1999. Functional analysis of the Pseudomonas syringae rulAB determinant in tolerance to ultraviolet $\mathrm{B}$ $(290-320 \mathrm{~nm})$ radiation and distribution of rulAB among $P$. syringae pathovars. Environ. Microbiol. 1:75-88.

42. Voloudakis, A. E., Bender, C. L., and Cooksey, D. A. 1993. Similarity between copper resistance genes from Xanthomonas campestris and Pseudomonas syringae. Appl. Environ. Microbiol. 59:1627-1634.

43. Yang, C.-H., Azad, H. R., and Cooksey, D. A. 1996. A chromosomal locus required for copper resistance, competitive fitness, and cytochrome $c$ biogenesis in Pseudomonas fluorescens. Proc. Natl. Acad. Sci. USA 93:7315-7320.

44. Zhou, C., Yang, Y., and Jong, A. Y. 1990. Miniprep in ten minutes. BioTechniques 8:172-173. 